\title{
Private Law in Eastern Europe
}

\section{Autonomous Developments or Legal Transplants? Ed. by Christa Jessel-Holst, Rainer Kulms and Alexander Trunk}

[Privatrecht in Osteuropa. Autonome Entwicklung oder Übernahme von Rechtssystemen?]

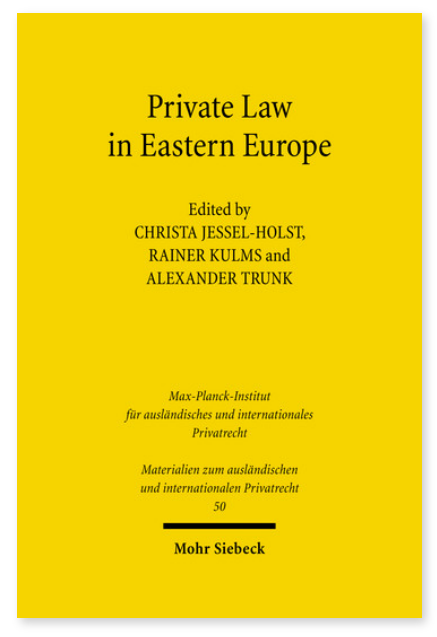

2010. XV, 503 Seiten. MatIPR 50

ISBN 978-3-16-151297-1

DOI 10.1628/978-3-16-151297-1

eBook PDF

ISBN 978-3-16-150589-8

Leinen $99,00 €$
Veröffentlicht auf Englisch.

Seit dem Zusammenbruch der sozialistischen Systeme sind mehr als zwanzig Jahre vergangen. Stand zunächst die Sicherung der Eigentumsordnung durch die gesetzliche Anerkennung von property rights unter marktwirtschaftlichen Bedingungen im Vordergrund, so hat sich die Kodifikationsdiskussion in Ost- und Südosteuropa und in den östlichen Mitgliedsstaaten der Europäischen Union schnell dem klassischen Zivilrecht und dem Gesellschaftsrecht zugewandt. Nach wie vor selten sind Untersuchungen, die den Transformationsprozess und seine Ergebnisse in langfristiger Perspektive analysieren und dabei die Entwicklungen in mehreren Staaten gegenüberstellen. Diese Lücke schließt ein Symposium, das im März 2009 in englischer Sprache am Hamburger Max-Planck-Institut für ausländisches und internationales Privatrecht stattgefunden hat.

Inhaltsübersicht

Jürgen Basedow: Welcome Address

A. Perspectives of Civil Law in Eastern Europe - Policy Issues

Rainer Kulms: Optimistic Normativism after Two Decades of Legal Transplants and Autonomous Developments - Michel Nussbaumer and Frederique Dahan: Promoting Legal Reform in Eastern Europe: the EBRD Approach - Thomas Meyer: Social Market Economy Values in Legal Reform Projects in South East Europe (SEE)

B. Civil Law - General Aspects

Alexander Komarov: Development of Private Law on Contracts in the Russian Federation - Volodymyr Kossak: General Principles of Private Law in Ukraine - Jelena Perović: Contract Law in Serbia - Camelia Toader: Contract Law in Romania Verica Trstenjak: Private Law Developments in Slovenia - a European Perspective - Christian Takoff: Private Law in Bulgaria

C. Property Law Aspects - South-Eastern Europe

Tatjana Josipović: Property Law Reform in Croatia Between Legal Transplants and Autonomous Development - Meliha Povlakić: Property Law in Bosnia and Herzegovina - Dušan Nikolić: Property Law in Serbia: Both Autonomous Legal Development and Legal Transplant

\section{Company Law in Eastern Europe}

Mirko Vasiljević : The Serbian Law on Commercial Companies - Alexandra Makovskaya : Russian Company and Capital Market Law - Oleg Zaitsev : 2009: Russian Corporate Legislation Reform Continues and Has to Be Continued - lonuţ Răduleţu: Recent Company Law Developments in the European Union - Tania Bouzeva: Company Law in Bulgaria - Radu N. Catană : Romanian Company Law: Recent Evolution Between Autonomous Development and Legal Transplants - András Kisfaludi: Company Law in Hungary - Krzysztof Oplustil and Arkadiusz Radwan: Company Law in Poland: Between Autonomous Development and Legal Transplants

Christa Jessel-Holst ist wissenschaftliche Mitarbeiterin am Max-Planck-Institut für ausländisches und internationales Privatrecht.

Rainer Kulms Dr. iur., LL.M. (Michigan); wiss. Referent am MPI für ausländisches und internationales Privatrecht; Privatdozent an der Universität Hamburg; Editor-in-Chief der European Business Organization Law Review (EBOR).

Alexander Trunk Keine aktuellen Daten verfügbar.

Jetzt bestellen:

https://mohrsiebeck.com/buch/private-law-in-eastern-europe-9783161512971?no_cache=1

order@mohrsiebeck.com

Telefon: +49 (0)7071-923-17

Telefax: $+49(0) 7071-51104$ 